\title{
耳奇形を伴ら先天性側頸瘻の一例
}

\section{永井 浩巳・新田健太郎・岡本 牧人・高橋 廣臣 \\ Lateral Cervical Fistula Originating from the Second Branchial Cleft; A Case Report}

\begin{abstract}
Hiromi Nagai, Hiroomi Takahashi, Makito Okamoto and Kentaro Nitta
\end{abstract}
(Kitasato University School of Medicine)

A 6-year-old boy, who had a lateral cervical fistula combined with congenital microtia and aural fistula is reported. The origin of the cervical fistula was the second branchial cleft. His mother also had congenital aural fistula and hearing impairment was noted in both his mother and his grandfather. The cervical fistula was totaliy removed by surgery under general anesthesia, histopathological study of the specimen revealed cutaneous appendages and lymphollicles.

One hundred and seventeen cases of lateral cervical fistula have been reported in Japan.

Malformation in the ear frequently occur from diturbance in embryonic development of the second branchial cleft. This is why the lateral cervical fistula originating from the second branchial cleft is combined with malformation in the ear. The pavement epithelium and cutaneous appendages originated from the embryonic ectoderm and lymphocytes from the endoderm.

Key words: Lateral cervical fistula, originating from the second branchial cleft, malfomation in the ear

はじめに

側頸瘦は胎生期の鰓裂由来の発生異常といわ れている.1789年に Funkzowsky および Dsondi によってはじめて報告され，それ以来本邦 でも数多く発表されて打り, 決して稀な疾患で はなくなっている。しかし今回我々は耳の奇形 を伴った側頸瘦を経験したので，その遺伝的背 景, 合併奇形につき検討し, 文献的考察を加え 報告した。

$$
\text { 症例 }
$$

患 者： 2 歳男子.
現病歴：1歳の頃, 言語発達の遅延があり, 某大学病院を受診した.ABR にて難聴を指摘 されるも，遠距離で通院困難なため当科を紹介 され昭和61年 1 月 8 日に受診した。

初診時所見：当科受診時の写真を図 1 に示す. 下顎は小さく, 右耳は耳介の奇形々外耳道の閉 鎖がみられ，また左耳前部には耳瘦孔を伴って いた，右前頸部，胸鎖乳突筋前縁で鎖骨より約 $2 \mathrm{~cm}$ 上方に瘦孔が存在し, 嶼下時に唾液の分 泌が認められた。 また瘦孔よりの分泌物の既往 はなく，索状物の触診も認められなかった。 
家族歴：母親に左の感音性難聴があり，右の 耳瘦孔と右側頸瘦が認められた（図 2 ). 瘦孔 からの分泌物は認められず, 瘦孔の感染の既往 もなかった。 また母方の祖父に難聴があった。 検査所見 :

(1) 瘦孔造影 : 瘦孔は頸部を扁桃上極方向に

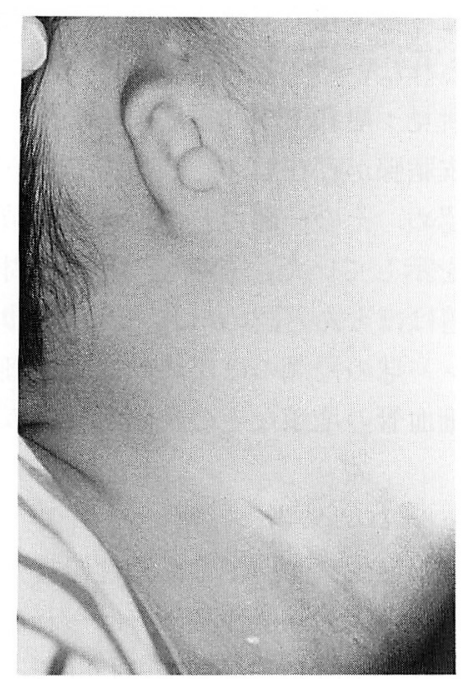

図 12 歳男児. 右耳奇形と耳瘦孔, 側頸㾇を示 す. 側頸瘦よりの分泌物の既往はない. 外 耳道は認められなかった。

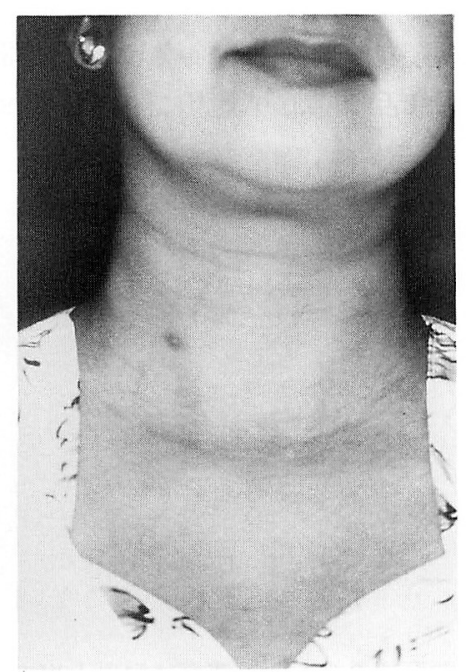

図 2 患児の母親. 右側頸瘦を示す. 右耳難聴を 示す。
上行していた。造影上では咽頭面への明らかな 開口部は確認できなかった。（図 3 )

（2）側頭骨 CT:右外耳道の閉鎖が認められ, 乳突蜂巣扣よび中耳の発育が不良で, 耳小骨も 存在しなかった。 また内耳道は正常であったが, 蝸牛の発育は不良であった。（図 4 ）

（3）聴力検查: $\mathrm{ABR}$ 域值は右は $60 \mathrm{~dB}$, 左 は $70 \mathrm{~dB}$ であった。

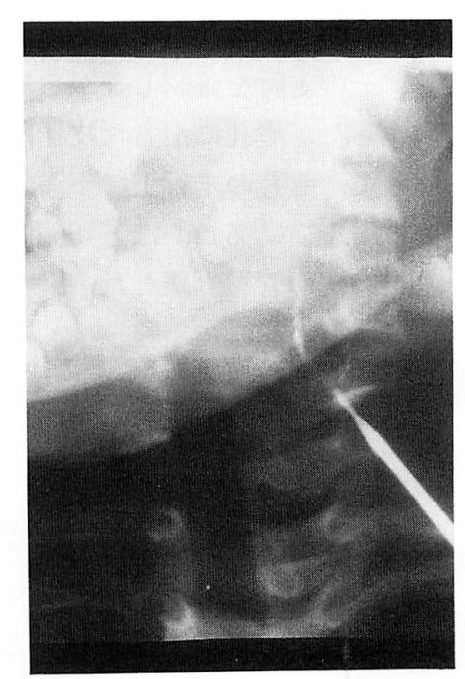

図 3 側頸㿉開口部上りの㾇管造影. 右扁桃上極 へと伸びている、咽頭内の開口部は明らか ではない。

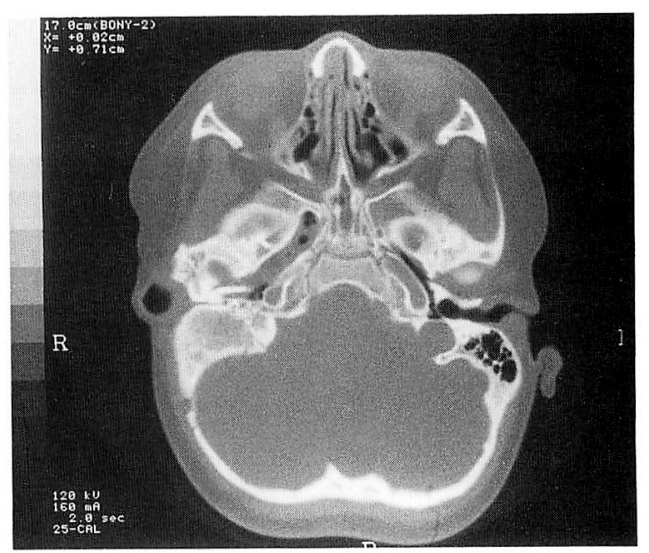

図 4 側頭骨の CT. 右の外耳道の閉鎖. 乳突蜂 栄, 蝸牛の発育は不良で专り, 半規管も はっきりしない。 
治 療：言語発達遅延と難聴については，言 語治療士とともに言語治療を行い，側頸㿉につ いては，感染も無く，身体も小さいため $4 \sim 5$ 歳まで経過観察をすることにした。４歳頃より 手術をすすめたが家族の承諾が兄られなかった。 6 歳になって, 就学前に行いたいといら家族の 意向があり, 平成元年 8 月 16 日側頸㾇摘出術を 全身麻酔下にて施行した.

手術所見：瘦孔の皮膚開口部の周囲を $2 \mathrm{~cm}$ 注ど紡錘形に切開し, 瘦孔に $2 \sim 0$ のナイロン 系を挿入し，その走行を確認しながら周囲組織 を上方に剥離した。瘦孔に沿った皮切は洀痕に なりやすいので，瘦孔の走行上で下顎骨より 2 横指下方の皮䖉を横に $5 \mathrm{~cm}$ 注ど切開し, さら にここより上方に瘦管を剥離した。戝 5 に示す

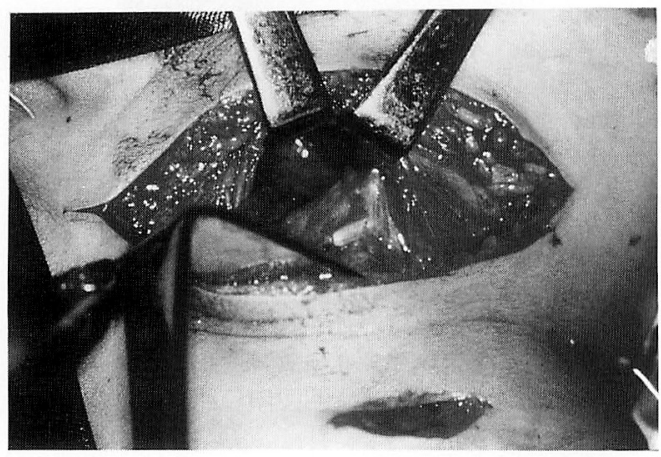

図 5 手術時の所見. 瘦管は頸動脈と舌下神経の 交叉上り $1.5 \mathrm{~cm}$ 上方から咽頭への走行で あった。

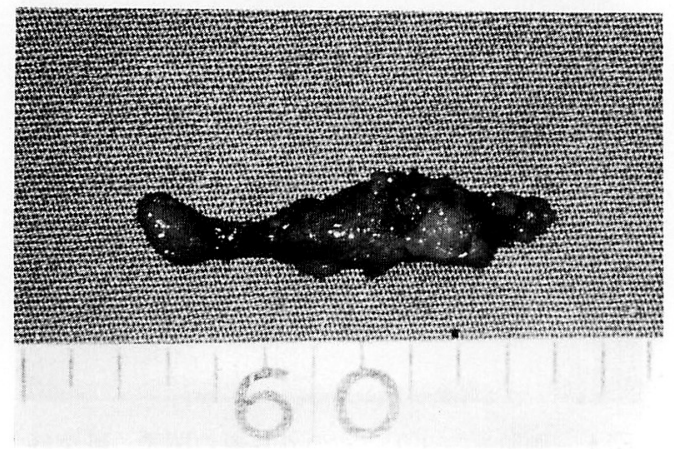

図 6 側頸瘦摘出. 長さ $4.0 \mathrm{~cm}$ で周囲組織とと もに断裂なく摘出した。
ように㾇管は胸鎖乳突筋に沿って上向し，内外 頸動脈の間を通り，頸動脈と舌下神経の交叉よ り $1.5 \mathrm{~cm}$ 上方から咽頭内へと入り, 扁桃上極 の扁桃窩に開口していた，㾇管を十分に追い， 開口部近くにて結杽し切断摘出した。摘出物を 図 6 亿示す。長さ $4.0 \mathrm{~cm}$ で，周囲組織ととも に途中断裂なく摘出した。術後経過は良好で術 後 1 年たった現在でも瘻孔の再交通や術創感染 は認められない。

病理所見：瘦孔上皮は重層扁平上皮で，午の 周囲は皮脂腺が存在し，それを覆うようにリン パ球を認め, その一部のリンパ球は集積し, 濾 胞形成を示していた。（図 7 ) 瘦孔は周囲組織 との㾑着は泀とんど認められず，側頸瘦にみら れるリンパ球の浸潤の汪かには, 炎症細胞の集 積や毛細血管の増殖などの炎症所見はみられな かった。

\section{考察}

側頸瘦の発生については, 鰓性器官の発生異 常説之組織の迷入，遺残説に分けられる. 前者 については, Rathke がブタの肧芽で，続いて Von Bear (1827) がヒトの肧芽で観察し側頸瘦 との関係を示し, Ascherson (1832)によっては じめて鰓性器官の発生異常のためと論じられた。 一方 Wengelowsky は胸腺咽頭説を掲げ，肧芽， 胎児, 成人の解剖例より検索し, 鰓性器官由来 の側頸瘻は舌骨位より上方に開口して拈り, 舌

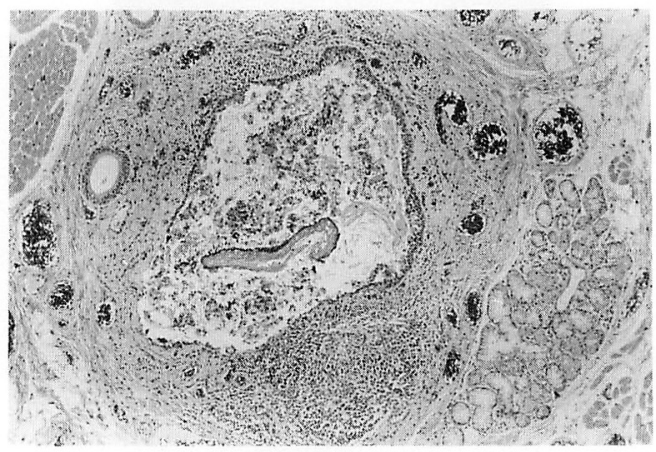

図 7 側頸瘻の横断面. 瘻管は扁平上皮にて被わ れており周囲に皮膚付属器とリンパ濾胞を 形成するリンパ球の浸潤を認める。 
骨位より下方では鰓弓由来ではなく, 胸腺咽頭 管の遺残ではないかと論じているが，第 4,5 鰓弓由来で舌骨位より下方に開口することも証 明されており，現在は否定的である4).

臨床像を本邦報告例117例について検討す る2) 21).（図 8 ）側頸瘦における男女差は明 らかではなく，ただ片側性は女性の発生率が高 かった．性差について諸家様々に論じて拈り， 猪野らの報告22) では男子に $3: 2$ と多いとし, 早坂ら ${ }^{23)}$ は, 本邦報告例では女性に多いとし ている.また小清水, 境らは性差はないといっ ている，遺伝性は117例中22例に認められ，男 女比は 4 対 3 で男に多く, 両側性が20例と多か った24). Baily (1923) によると遺伝因子は母親 より伝達されると報告されている25)。これは本 症例についても合致した.

合併奇形は117例中35例にみられ, 男女比は 1 対 1 であり，両側性のものが29例を占めた ${ }^{26)}$. 合併奇形の中では耳瘦孔が34例ともっとも多く, 難聴を示すものは 5 例にとどまった。また鰓性 器官以外の合併奇形としてはへルニア1例のみ であった．本症例でも，頸部と耳の奇形の他は，

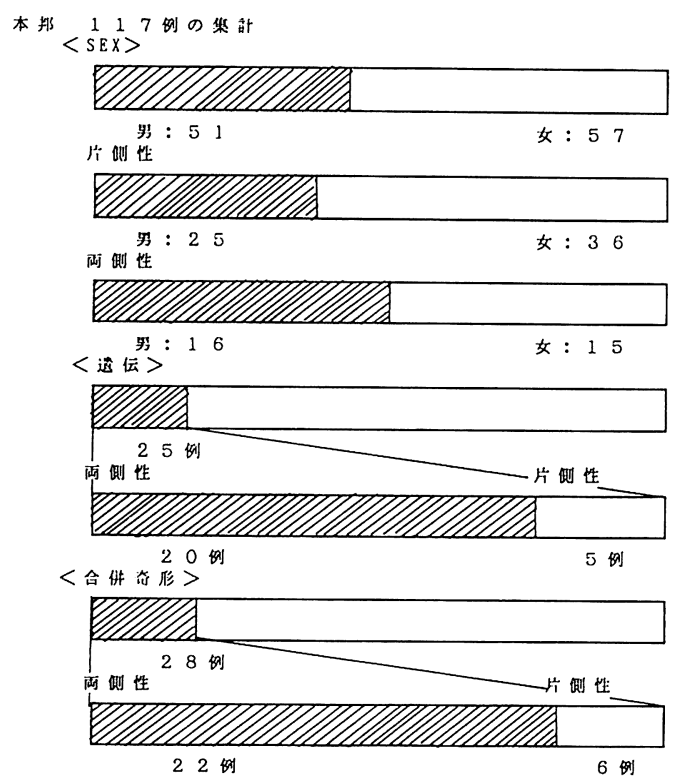

図 8 本邦117例の集計
とくに身体的異常は認められなかった．このこ とより側頸瘦は全身的奇形といらょりは鰓性器 官の局所的奇形と考えられる.

耳瘦孔合併奇形例について側頸瘦の発生鰓裂 をみると，第 2 鰓裂由来の側頸瘦が汪とんどで あった。田中らは耳㾇孔は耳介を形成する第 1 鰓弓と第 2 鰓弓の間に生じるもので, 第 1 鰓裂 の側頸瘦に合併するとしている27) が，本邦報 告例より考学ると否定的で, 相見らが示す28)29) ように，第 1 鰓裂の消失が胎生 2 力月末に完成 しているのに対し，耳介形成は胎生40日頃より 始まって扣り，両者の間に期間のずれがある. このことより第 1 鰓裂に耳瘦孔が合併するより むしろもっとも長い期間存在する第 2 鰓裂に合 併しやすいと考えられる30). 本症例についても， 手術所見より第 2 鰓裂由来の側頸㾞で耳介奇形 と耳瘦孔を伴っていた。

病理組織学的に出現したリンパ球が先天性か, 感染による二次性の変化かを検討してみると， 本邦報告例117例ではそのほとんどが感染性の 変化を示しており, 本症例のような非感染例は 8 例にとどまっていた 31) 33)．また瘻管の上皮 について検討すると，多くは重層扁平上皮であ るのに対し，8例に絨毛上皮を含むものがあっ た. そしてその 5 例は感染の既往はなかった. このことから側頸瘦の重層扁平上皮は初めは内 胚葉の絨毛上皮と外胚葉の扁平上皮が存在し， これが生後の感染のため一部絨毛上皮が扁平上 皮化生を示していると考えられる。本症例では 瘦孔が重層扁平上皮に被われ，皮膚付属器を持 ち, 多くのリンパ球の集積を示していた. しか し慢性炎症の既往がないため, このリンパ球は 慢性炎症によるものでなく，発生段階における 中胚葉由来のものと考兄られ，また㿉管の扁平 上皮も炎症による扁平上皮化生ではなく，外肧 葉由来のものと思われた.

\section{おわりに}

耳の奇形を伴ら側頸瘻につき，本邦文献報告 例を加え検討した。

（1）合併奇形は第 2 鰓裂に多く，その奇形も 
鰓性器官異常であった。このことは本症例にも 合致していた.

（2）本症例は瘦孔上皮を重層扁平上皮で被わ れ，一部濾胞を形成する多くのリンパ球を有し た. この性状より, 内胚葉と外胚葉の混在が考 えられた。

稿を終えるに臨み御指導, 御校閲いただきました 北里大学病院耳鼻咽喉科教室設楽哲也教授, 徳増厚 二教授に深謝いたします。

尚, 本論文の一部は頭頸部外科耳鼻咽喉科神奈川 県地方会において口頭発表した。

\section{参考文献}

1）梅田良三，渡辺幸夫，大城功也，他 : 先天性側 頸瘦の 1 例. 耳鼻臨床 $64: 1341 \sim 1344,1971$.

2）古川雅禎, 中川浩一, 横川真弓, 他 : 先天性頸 耳瘦. 皮膚臨床 $30: 689 \sim 692,1988$.

3）原田玲子, 磯貝 豊: 先天性側頸瘦の一例. 臨 皮 $37: 7 ; 613 \sim 619,1983$.

4）岩浅武彦, 宮川 信, 牧内正夫, 他 : 第 1 鰓裂 由来の側頸瘦の一例.外科 $36: 616 \sim 620,1977$.

5）山名忠巳, 伊東久太郎：両側先天性耳瘦孔と先 天性側頸瘦を合併する先天性沃整瘦の一例. 眼 紀 33：1039〜1043, 1982.

6) 井沢豊明, 浜野 嚴, 本郷 裕：稀有なる側頸 㿉に就て。耳展 $123: 269 \sim 126: 272,1958$.

7）村田行孝, 橋本 俊, 清水保延, 他: 頸部先天

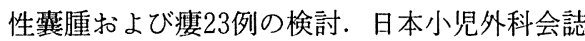
$23: 6 ; 1023 \sim 1029,1987$.

8）松原 浄, 小倉義郎：複雑な走行を呈した第 1 鰓裂瘦孔の一例。日耳鼻 $80: 542,1977$.

9) 藤田 寛, 松本 康: 両側側頸瘦孔・耳瘦孔の 一例. 日耳鼻 $83: 1668,1980$.

10）田所広文, 柳原尚明：兄弟にみられた側頸瘦, 混合難聴,内耳道異常合併例. 日耳鼻 $83: 856$, 1980.

11）関 六郎：中耳に交通せる先天性側頸瘦. 日耳 鼻 $64: 1169,1961$

12）谷 義行：母子にみられた完全側頸瘦及び不完 全側頸瘦の症例。日耳鼻 $73: 1397,1970$ 。

13）行木英生, 大塚 護, 岡田康司 : 最近経験した 先天性側頸瘦管拈よび慗腫. 日気食会報 $29: 2$; 105 106, 1978.
14）辻 一江：咽頭息室を伴う側頸瘦の一例. 日耳 鼻 $75: 721,1972$.

15）野口昌邦，素谷 宏，竹下八州男：父子にみら れた先天性耳瘦を伴った両側性側頸瘦. 日外会 誌 $77: 9 ; 1322,1976$.

16）浜田 寬，平林金一，長沼栄一：双生児にみら れた先天性両側性不完全側頸瘦の 2 例. 耳展 $31: 2 ; 149 \sim 150,1958$.

17）小山信弥，加藤 治，平野敬八朗：濃厚なる家 族性発生をみた両側先天性耳瘦孔を伴った両側 先天性側頸瘦の 1 例. 日小児外科会誌 $12: 1$; 138, 1976.

18）高柳 裕, 安保純朗, 伊東昭一朗, 他 : 先天性 側顓瘦の興味ある 1 例. 診療 $13: 224 \sim 227$, 1960.

19）執行英毅，小池靖夫：先天性側頸瘻の 1 例. 耳 鼻臨床 $50: 298,1958$.

20）堀隆，野沢博正，横森欣司：反復性化膿性 甲状腺炎と誤られていた稀な側頸瘦の 1 例. 日 小児外科会誌 $14: 514,1978$.

21）長沢賢一, 二瓶誠五：両側先天性側頸瘦症例. 耳鼾臨床 $46: 22 \sim 24,1953$.

22）猪野 満,一戸兵部, 田中隆夫：先天性頸賴腫 （瘦）の 8 例. 外科治療 $22: 3 ; 354 \sim 356,1970$.

23）早坂 晃, 白松幸嗣 : 先天性頸瘦之頸瘦胞. 外 科診療 $9: 1043 \sim 1053,1971$.

24）池田恵一：頸部の先天性瘦孔拈よび腫瘤. 外科 $45: 11 ; 1169 \sim 1174,1983$.

25）松村長生, 大塩猛人, 河内 護: 先天性両側性 側頸瘦の家族内発生例。 小览外科 $13: 2 ; 139 \sim$ 142, 1981

26）武本欣也，高橋広臣，川野六郎：両側先天性完 全側頸瘦症例. 耳喉 $48 ： 7 ; 493 \sim 498,1976$.

27）田中幹夫，小林武夫，奥村哲治，他 : 第 1 鰓裂 由来の側頸瘻の一症例. 日耳鼻 $91: 710 \sim 723$, 1988.

28）相見賢治：先天性側頸部瘦管及び褧腫に関する 考察. 日耳鼻 $69:$ 1919 1933, 1966.

29）寺山吉彦，八代利雄，吉野成一，他 : 先天性耳 瘦孔を合併する両側先天性側頸瘦の一例. 耳喉 $34: 6 ; 411 \sim 413,1956$.

30）小池 真, 伊藤寿雄, 渡辺克益, 他: 先天性頸 耳瘦（第 1 鰓裂奇形）の 1 治験例. 形成外科 $18: 249 \sim 253,1975$. 
31）清田隆二, 古田 茂, 山本 誠, 他: 先天性側 頸瘦一興味ある 2 治験例と文献的考察一. 耳鼻 $28: 188 \sim 195,1982$.

32）北村博之, 齋藤春雄, 宮本和雄, 他 : 第 1 鰓裂 由来の側頸瘦及び唑腫. 耳鼻臨床 $71: 967 \sim 975$, 1978.

33）園部友良, 野沢博正, 堀隆 : 反復性化膿性
甲状腺炎をひきおこした先天性側頸瘦の一例。 小児科臨床 $34: 4 ; 1981$.

$$
\left(\begin{array}{l}
\text { 別刷請求先 : 永井浩巳 } \\
\text { ₹228 相模原市北里 } 1-15-1 \\
\text { 北里大学医学部耳鼻咽喉科学教室 }
\end{array}\right)
$$

